\title{
In vitro SUSCEPTIBILITY TESTING OF DERMATOPHYTES ISOLATED IN GOIANIA, BRAZIL, AGAINST FIVE ANTIFUNGAL AGENTS BY BROTH MICRODILUTION METHOD
}

Crystiane Rodrigues ARAÚJO, Karla Carvalho MIRANDA, Orionalda de Fatima Lisboa FERNANDES, Ailton José SOARES \& Maria do Rosário Rodrigues SILVA

\begin{abstract}
SUMMARY
The antifungal activities of fluconazole, itraconazole, ketoconazole, terbinafine and griseofulvin were tested by broth microdilution technique, against 60 dermatophytes isolated from nail or skin specimens from Goiania city patients, Brazil. In this study, the microtiter plates were incubated at $28{ }^{\circ} \mathrm{C}$ allowing a reading of the minimal inhibitory concentration (MIC) after four days of incubation for Trichophyton mentagrophytes and five days for T. rubrum and Microsporum canis. Most of the dermatophytes had uniform patterns of susceptibility to the antifungal agents tested. Low MIC values as $0.03 \mu \mathrm{g} / \mathrm{mL}$ were found for $33.3 \%, 31.6 \%$ and $15 \%$ of isolates for itraconazole, ketoconazole and terbinafine, respectively.
\end{abstract}

KEYWORDS: Dermatophytes; Broth microdilution method; Minimal Inhibitory Concentration.

\section{INTRODUCTION}

Dermatophytosis, mycotic infections caused by dermatophytes, are commonly related in tropical countries and represent an important public health problem yet unresolved ${ }^{4}$. Trychophyton rubrum, T. mentagrophytes and Microsporum canis are the most common species isolated in Brazil as causative agents of dermatophytosis ${ }^{1,6,7,8,21}$. In Goiania city, Brazil, these same etiological agents have been recovered in studies of COSTA et al..$^{6,7}$. Antifungal agents such as triazoles (itraconazole, fluconazole), imidazole (ketoconazole), allylamine (terbinafine) and griseofulvin have been reported to have substantial activity in dermatophytosis ${ }^{16,17}$. However, infections due to dermatophytes are often associated with relapses after cessation of therapy ${ }^{20}$. By the way, in vitro antifungal susceptibility tests could help to optimize the therapy and to select an effective antifungal agent for this mycosis ${ }^{3}$. A standard method for susceptibility testing of dermatophytes is lacking, but good results of MIC using either broth macrodilution or broth microdilution tests have been obtained in several reports $9,10,12,18$. The purpose of this work was to establish the in vitro antifungal susceptibility of fluconazole, itraconazole, ketoconazole, terbinafine and griseofulvin against clinical dermatophytes isolated in Goiania-GO, Brazil, using the broth microdilution method.

\section{MATERIALS AND METHODS}

Organisms: A total of 60 dermatophyte strains, including Trichophyton rubrum $(\mathrm{n}=27)$, T. mentagrophytes $(\mathrm{n}=14)$ and Microsporum canis $(\mathrm{n}=19)$ were tested. All microorganisms were clinical isolates obtained from nail or skin specimens recovered from patients from Goiania University Hospital from March to July 2006. The fungi were maintained in sterile distilled water at room temperature and prior to testing, the strains were subcultured on potato dextrose agar (PDA) at $28^{\circ} \mathrm{C}$ for seven to 15 days to ensure the viability and the purity of the inoculum. Candida parapsilosis ATCC 22019 was included as reference strain.

In vitro susceptibility testing: The broth microdilution assay for antifungal susceptibility testing of dermatophytes was performed, when possible according to the CLSI guidelines in the document M38-A of filamentous fungi ${ }^{5}$.

Antifungal drugs dilution: The drugs were obtained from their respective manufacturers: fluconazole (Pfizer International, New York, NY), ketoconazole, itraconazole (Jansen Pharmaceuticals, Beerse, Belgium), terbinafine (Novartis Research Institute, Vienna, Austria) and griseofulvin (Sigma Chemical Company, St. Louis, Mo). Fluconazole was dissolved in distilled water while the other drugs were dissolved in $100 \%$ dimethyl sulfoxide (Sigma-Aldrich). They were subsequently prepared as stock solution and serial twofold dilutions were performed. Final concentrations ranged from 0.125 to $64 \mu \mathrm{g} / \mathrm{mL}$ for fluconazole, 0.03 to $16 \mu \mathrm{g} / \mathrm{mL}$ for ketoconazole, itraconazole and terbinafine, and 0.03 to $8 \mu \mathrm{g} / \mathrm{mL}$ for griseofulvin.

Test procedure: Inoculum suspensions of dermatophytes were prepared from the seven days cultures grown on potato dextrose agar at $28{ }^{\circ} \mathrm{C}$. The fungal colonies were covered with approximately 10

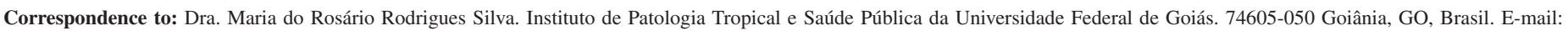
rosario@iptsp.ufg.br 


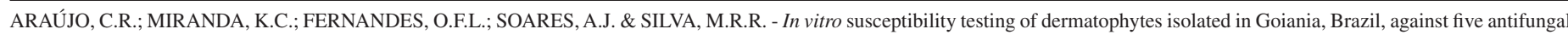
agents by broth microdilution method. Rev. Inst. Med. trop. S. Paulo, 51(1): 9-12, 2009.

$\mathrm{mL}$ of distilled water, and the suspensions were made by scraping the surface with the tip of a sterile loop. The resulting mixture of conidia and hyphal fragments was withdrawn and transferred to sterile tubes and left for 15 to 20 minutes at room temperature to sediment the heavy particles. The optical density of the suspensions containing conidia and hyphal fragments was read at $530 \mathrm{~nm}$, adjusted to transmittance of 65 to $70 \%$ ( $~ 2$ to 4 X $10^{6}$ cells $/ \mathrm{mL}$ ) and diluted with RPMI 1640 medium (Sigma Chemical Co., St. Louis, Mo) to obtain the final inoculum size of approximately 0.4 to $5 \times 10^{4}$ cells $/ \mathrm{mL}$. Aliquots of $100 \mu \mathrm{L}$ of these suspensions were inoculated in well of microtiter plate containing 100 $\mu \mathrm{L}$ of specific antifungal drug concentration and incubated at $28^{\circ} \mathrm{C}$. Each assay was carried out in duplicate.

Endpoint determination: Endpoint determination values were performed visually every $24 \mathrm{~h}$ until the indication of growth in control well drug-free. For azole agents and griseofulvin, the MIC was defined as the lowest concentration that produced prominent inhibition of growth (approximately 80\% inhibition) while for terbinafine, was defined as lowest concentration showing $100 \%$ growth inhibition ${ }^{23}$.

\section{RESULTS}

MICs of antifungal agents for 60 dermatophytes isolates could be determined after four days for T. mentagrophytes and five days for $T$. rubrum and $M$. canis when incubated at $28^{\circ} \mathrm{C}$.

In general, the species of dermatophytes showed similar patterns of susceptibility to each antifungal agent tested. The determination of the isolates as susceptible or resistant is complex and not yet been established for dermatophytes, but high MIC values were found for some isolates. Seven (11.6\%) dermatophytes strains (five T. rubrum and two M. canis) had MICs of fluconazole of $32 \mu \mathrm{g} / \mathrm{mL}$, five (8.3\%) strains (four T. rubrum and one $M$. canis) had MICs of ketoconazole of $4 \mu \mathrm{g} / \mathrm{mL}$ and one $M$. canis isolate had MIC of $8 \mu \mathrm{g} / \mathrm{mL}$ for griseofulvin. However most isolates showed low MIC values, being that $33.3 \%, 31.6 \%$ and $15 \%$ of isolates had MIC of $0.03 \mu \mathrm{g} / \mathrm{mL}$ for itraconazole, ketoconazole and terbinafine, respectively.

Table 1 summarizes the MIC ranges, concentrations inhibiting 50\% $\left(\mathrm{MIC}_{50}\right)$ and $90 \%\left(\mathrm{MIC}_{90}\right)$ of the isolates and geometric mean of the MICs of the five antifungal drugs against 60 strains of dermatophytes.

The MIC ranges of fluconazole, itraconazole and ketoconazole for C. parapsilosis ATCC 22019 were within the values standardized by CLSI document M-38-A.

\section{DISCUSSION}

The determination of the in vitro susceptibility may prove helpful to predict the ability of a given antifungal agent to eradicate dermatophytes. Although a reference method for dermatophytes, is not available, a good correlation between the in vitro data, using broth microdilution method, and clinical outcome has been demonstrated ${ }^{19}$.

Some recommendations, as temperature and duration of incubation used in the broth microdilution method according with the document $\mathrm{M}$

Table 1

In vitro activities of five antifungal agents against 60 strains of dermatophytes isolated from patients from Goiania University Hospital from March to July 2006

\begin{tabular}{|c|c|c|c|c|c|}
\hline \multirow{2}{*}{$\begin{array}{l}\text { Species } \\
\text { (No. of isolates) }\end{array}$} & \multirow[t]{2}{*}{ Antifungal agents } & \multicolumn{4}{|c|}{$\mathrm{MIC}(\mu \mathrm{g} / \mathrm{mL})$} \\
\hline & & Range & $\mathrm{MIC}_{50}$ & $\mathrm{MIC}_{90}$ & Geometric mean \\
\hline T. rubrum & Fluconazole & $2-32$ & 8 & 32 & 7.60 \\
\hline \multirow[t]{4}{*}{ (27) } & Itraconazole & $0.03-4$ & 0.125 & 0.5 & 0.10 \\
\hline & Ketoconazole & $0.03-4$ & 0.06 & 4 & 0.13 \\
\hline & Terbinafine & $0.03-0.5$ & 0.125 & 0.25 & 0.11 \\
\hline & Griseofulvin & $0.25-2$ & 0.5 & 1 & 0.65 \\
\hline T. mentagrophytes & Fluconazole & $4-16$ & 16 & 16 & 11.31 \\
\hline \multirow[t]{4}{*}{ (14) } & Itraconazole & $0.03-0.25$ & 0.125 & 0.25 & 0.09 \\
\hline & Ketoconazole & $0.03-1$ & 0.125 & 0.25 & 0.12 \\
\hline & Terbinafine & $0.03-0.5$ & 0.06 & 0.25 & 0.08 \\
\hline & Griseofulvin & $0.25-1$ & 0.5 & 0.5 & 0.45 \\
\hline M. canis & Fluconazole & $2-32$ & 8 & 16 & 9.96 \\
\hline \multirow[t]{4}{*}{ (19) } & Itraconazole & $0.03-0.25$ & 0.125 & 0.25 & 0.08 \\
\hline & Ketoconazole & $0.03-4$ & 0.125 & 0.25 & 0.12 \\
\hline & Terbinafine & $0.03-1$ & 0.125 & 0.25 & 0.11 \\
\hline & Griseofulvin & $0.06-8$ & 0.25 & 0.5 & 0.31 \\
\hline
\end{tabular}

MIC - minimal inhibitory concentration; $\mathrm{MIC}_{50}$ and $\mathrm{MIC}_{90}$ - MIC inhibiting $50 \%$ and $90 \%$ of the isolates 
ARAÚJO, C.R.; MIRANDA, K.C.; FERNANDES, O.F.L.; SOARES, A.J. \& SILVA, M.R.R. - In vitro susceptibility testing of dermatophytes isolated in Goiania, Brazil, against five antifungal agents by broth microdilution method. Rev. Inst. Med. trop. S. Paulo, 51(1): 9-12, 2009.

38-A of filamentous fungi were modified in this study. In this document, the temperature at $35{ }^{\circ} \mathrm{C}$ is used for incubation; however we used for dermatophytes the temperature at $28^{\circ} \mathrm{C}$ according to BARROS et al. ${ }^{2}$ and SANTOS et al..$^{23}$ which obtained success in their results. Studies of in vitro susceptibility testing for dermatophytes previously performed in our laboratory showed that the MIC values were easier to read and to interpret (a good visualization of the growth) when the microtiter plates were incubated at $28^{\circ} \mathrm{C}$ than at $35^{\circ} \mathrm{C}$ (data not shown). It is well known that an optimal growth on culture media is obtained by dermatophytes strains when incubated between $28^{\circ} \mathrm{C}$ and $30^{\circ} \mathrm{C}^{9,11,22}$. The document M38-A establish 24 to $72 \mathrm{~h}$ of incubation for filamentous fungi, however, in our work, a detectable growth was observed after four days for $T$. mentagrophytes and after five days for T. rubrum and $M$. canis. The ideal incubation time is still a matter of debate. FERNÁNDEZ-TORRES et al. ${ }^{13}$, SANTOS et $a l .{ }^{23,24}$ found that seven days was sufficient to observe prominent growth in control wells, while GHANNOUM et al. ${ }^{14}$ and JESSUP et al. ${ }^{18}$ verified growth in four days at $28^{\circ} \mathrm{C}$.

In our work, the evaluation of in vitro susceptibility showed that the antifungal drugs tested, with exception of fluconazole, displayed good activity against the dermatophytes. It is worth mentioning that itraconazole, ketoconazole and terbinafine had the lowest MIC values and geometric means. Similar results have been verified by other authors that showed that these drugs had low MICs against dermatophytes ${ }^{10,12,15}$. These low MICs found for the three drugs can help to explain the promising results obtained for the treatment of dermatophytosis with these antifungal agents ${ }^{19}$.

Although fluconazole has showed the highest MIC values of all the antifungal agents tested, we verified that T. rubrum strains, one specie that cause a recalcitrant chronic disease, were more susceptible to this drug than T. mentagrophytes and M. canis isolates (geometric mean of 7.60 for T. rubrum, 9.96 for $M$. canis and 11.31 for T. mentagrophytes). Our results are similar to FERNÁNDEZ-TORRES et al..$^{10}$ who demonstrated higher activity of fluconazole for T. rubrum than for T. mentagrophytes, M. canis and M. gypseum.

In summary, the parameters as temperature at $28{ }^{\circ} \mathrm{C}$, incubation time of five days and inoculum of 0.4 to $5 \times 10^{4}$ cells $/ \mathrm{mL}$ allowed the determination of MIC for dermatophytes by using the microdilution method. Besides, our work demonstrated that in vitro different antifungal agents are active against dermatophytes independent of specie.

\section{RESUMO}

Teste de suscetibilidade in vitro de dermatófitos isolados em Goiânia, Brasil, contra cinco agentes antifúngicos pelo método de microdiluição em caldo

Atividades antifúngicas de fluconazol, itraconazol, cetoconazol, terbinafina e griseofulvina foram testadas pelo método de microdiluição em caldo contra 60 isolados de dermatófitos. Os resultados mostraram que todos os isolados produziram crescimento claramente detectável a $28^{\circ} \mathrm{C}$ e a concentração inibitória mínima (CIM) foi determinada após quatro dias de incubação para Trichophyton mentagrophytes e cinco dias para T. rubrum e Microsporum canis. A maioria dos isolados teve um padrão uniforme de suscetibilidade para os agentes antifúngicos testados. Baixos valores de CIM como $0,03 \mu \mathrm{g} / \mathrm{mL}$ foram encontrados para $33,3 \%, 31,6 \%$ e $15 \%$ dos isolados para itraconazol, cetoconazol e terbinafina, respectivamente.

\section{REFERENCES}

1. ARAÚJO, A.J.G.; BASTOS, O.M.P.; SOUZA, M.A.J. \& OLIVEIRA, J.C. Ocorrência de onicomicose em pacientes atendidos em consultórios dermatológicos da cidade do Rio de Janeiro, Brasil. An. bras. Derm., 78: 299-308, 2003.

2. BARROS, M.E.S.; SANTOS, D.A. \& HAMDAN, J.S. - Evaluation of susceptibility of Trichophyton mentagrophytes and Trichophyton rubrum clinical isolates to antifungal drugs using a modified CLSI microdilution method (M38-A). J. clin. Microbiol., 56: 514-518, 2007.

3. CARRILlO-MUNÕZ, A.J.; QUINDÓS, G.; RUESGA, M. et al. - In vitro susceptibility testing of filamentous fungi with Sensititre Yeast $\mathrm{One}^{\mathrm{TM}}$. Mycoses, 49: 293-297, 2006.

4. CHINElli, P.A.V.; SOFiATti, A.A.; NUNES, R.S. \& MARTins, J.E.C. Dermatophyte agents in the city of São Paulo, from 1992 to 2002. Rev. Inst. Med. trop. S. Paulo, 45: 259-263, 2003.

5. CLINICAL AND LABORATORY STANDARDS INSTITUTE - Reference method for broth dilution antifungal susceptibility testing of filamentous fungi. Wayne, CLSI, 2002. (Approved Standard M38-A).

6. COSTA, M.; PASSOS, X.S.; SOUZA, L.K.H. et al.- Epidemiologia e etiologia das dermatofitoses em Goiânia, GO, Brasil. Rev. Soc. bras. Med. trop., 35: 19-22, 2002

7. COSTA, T.R.; COSTA, M.R.; SILVA, M.V. et al. - Etiologia e epidemiologia das dermatofitoses em Goiânia, GO, Brasil. Rev. Soc. bras. Med. trop., 32: 367-371, 1999.

8. DIAS, T.; FERNANDES, O.F.L.; SOARES, A.J. et al. - Tinha do couro cabeludo em crianças de Goiânia, Brasil. Rev. Soc. bras. Med. trop., 36: 653-655, 2003.

9. FERNÁNDEZ-TORRES, B.; VÁZQUEZ-VEIGA, H.; LIOVO, X.; PEREIRO Jr., M \& GUARRO, J. - In vitro susceptibility to itraconazole, clotrimazole, ketoconazole and terbinafine of 100 isolates of Trichophyton rubrum. Chemotherapy, 46: 390-394, 2000 .

10. FERNÁNDEZ-TORRES, B.; CARRILLO, A.J.; MARTÍN, E. et al. - In vitro activities of 10 antifungal drugs against 508 dermatophyte strains. Antimicrob. Agents Chemother., 45: 2524-2528, 2001.

11. FERNÁNDEZ-TORRES, B.; CABAÑES, F.J.; CARRILLO-MUNÕZ, A.J. et al. - Collaborative evaluation of optimal antifungal susceptibility testing condition for dermatophytes. J. clin. Microbiol., 40: 3999-4003, 2002.

12. FERNÁNDEZ-TORRES, B.; CARRILlO-MUÑOZ, A.; ORTOPEDA, M. et al. - Interlaboratory evaluation of the Etest ${ }^{\circledast}$ for antifungal susceptibility testing of dermatophytes. Med. Mycol., 41: 125-130, 2003.

13. FERNÁNDEZ-TORRES, B.; INZA, I. \& GUARRO, J. - In vitro activities of the new antifungal drug eberconazole and three other topical agents against 200 strains of dermatophytes. J. clin. Microbiol., 41: 5209-5211, 2003.

14. GHANNOUM, M.A.; CHATURVEDI, V.; ESPINEL-INGROFF, A. et al. - Intra and interlaboratory study of a method for testing the antifungal susceptibilities of dermatophytes. J. clin. Microbiol., 42: 2977-2979, 2004.

15. GHANNOUM, M.A.; WRAITH, L.A; CAI, B.; NYIRADY, J. \& ISHAM, N. Susceptibility of dermatophytes isolates obtained from a large worldwide terbinafine tinea capitis clinical trial. Brit. J. Derm., 159: 711-713, 2008.

16. GUPTA, A.K. \& DEL ROSSO, J.Q. - An evaluation of intermittent therapies used to treat onychomycosis and other dermatomycoses with the oral antifungal agents. Int. J. Derm., 39: 401-411, 2000. 
ARAÚJO, C.R.; MIRANDA, K.C.; FERNANDES, O.F.L.; SOARES, A.J. \& SILVA, M.R.R. - In vitro susceptibility testing of dermatophytes isolated in Goiania, Brazil, against five antifungal agents by broth microdilution method. Rev. Inst. Med. trop. S. Paulo, 51(1): 9-12, 2009.

17. HAINER, B.L. - Dermatophyte infections. Amer. Fam. Physic., 67: 101-108, 2003.

18. JESSUP, C.J.; WARNER, J.; ISHAM, N.; HASAN, I. \& GHANNOUM, A. Antifungal susceptibility testing of dermatophytes: establishing a medium for inducing conidial growth and evaluation of susceptibility of clinical isolates. J. clin. Microbiol., 38: 341-344, 2000.

19. KORTING, H.C.; OLLERT, M. \& ABECK, D. - Results of German multicenter study of antimicrobial susceptibilities of Trichophyton rubrum and Trichophyton mentagrophytes strains causing tinea unguium. German Collaborative dermatophyte drug susceptibility study group. Antimicrob. Agents Chemother., 39: 1206-1208, 1995.

20. MUKHERJEE, P.K.; LEIDICH, S.D.; ISHAM, N. et al. - Clinical Trychophyton rubrum strain exhibiting primary resistance to terbinafine. Antimicrob. Agents Chemother., 47: 82-86, 2003.
21. OLIVEIRA, J.A.A.; BARROS, J.A.; CORTEZ, A.C.A. \& OLIVEIRA, J.S.R.L. Micoses superficiais na cidade de Manaus, AM, entre março e novembro/2003. An. bras. Derm., 81: 238-243, 2006.

22. PUJOL, I.; CAPILLA, J.; FERNÁNDEZ-TORRES, B.; ORTONEDA, M. \& GUARRO, J. - Use of the sensititre colorimetric microdilution panel for antifungal susceptibility testing of dermatophytes. J. clin. Microbiol., 40: 2618-2621, 2002.

23. SANTOS, D.A.; BARROS, M.E.S. \& HAMDAN, J.S. - Establishing a method of inoculum preparation for susceptibility testing of Trichophyton rubrum and Trichophyton mentagrophytes. J. clin. Microbiol., 44: 98-101, 2006.

24. SANTOS, D.A. \& HAMDAN, J.S. - In vitro activities of four antifungal drugs against Trichophyton rubrum isolates exhibiting resistance to fluconazole. Mycoses, 50: 286-289, 2007.

Received: 31 March 2008

Accepted: 3 November 2008 